\title{
Profil Implementasi Model Connected Pada Pembelajaran IPA di Indonesia : Kajian Literatur 2012-2021*
}

\author{
${ }^{*}$ M. Raynaldi Rosyidi Zamil1, Putrie Syifa Udyaningsih ${ }^{2}$ \\ 1 Universitas Negeri Surabaya, Surabaya, Indonesia \\ 2 Universitas Negeri Semarang, Semarang, Indonesia
}

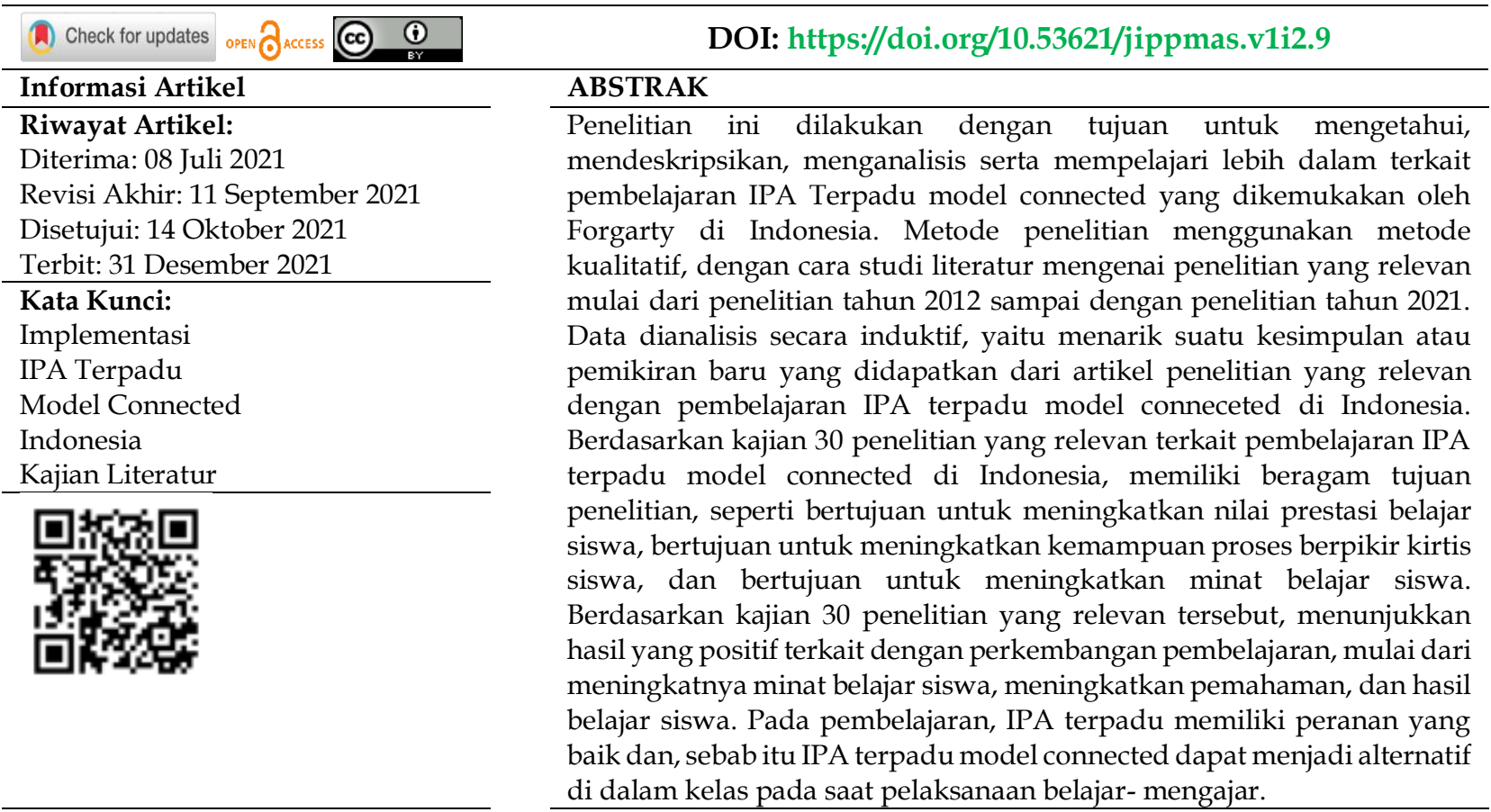

\section{PENDAHULUAN}

Pendidikan merupakan salah satu hal yang penting di era abad 21 ini, oleh karena itu perlu adanya sistem pendidikan yang baik, sehingga dapat menghasilkan generasigenerasi yang memiliki dasar pendidikan dan intelektual yang baik. Dengan pendidikan maka ilmu yang telah didapat tersebut akan dapat berguna untuk dirinya sendiri, orang lain, hingga berguna bagi bangsa dan negara. Pendidikan merupakan bentuk ciptaan manusia sebagai suatu sarana dengan tujuan untuk menciptakan hidup yang lebih baik (Partini et al., 2012). Upaya sudah banyak dilakukan demi meningkatkan kualitas pendidikan. (Oktamagia et al., 2013). Dalam mengenyam pendidikan, tidak akan lepas dari mata pelajaran IPA. IPA atau sains adalah ilmu relevan (Makhrus \& Hadiprayitno, 2012). Pembelajaran IPA terdiri dari kimia, biologi, serta fisika yang saling terkait. Namun kenyataanya, ketiga aspek tersebut diajarkan secara terpisah. Contoh, guru fisika hanya mengajarkan mata pelajaran fisika saja, begitu pula dengan guru kimia dan juga biologi. Hal tersebut yang menyebabkan pembelajaran IPA yang didapat siswa tidak dapat menangkap konsep IPA secara utuh (S. Fitriani et al., 2012). Mencapai tujuan dari pendidikan untuk memperbaiki SDM dapat tercapai lewat pelajaran IPA, yaitu mata pelajaran yang bertujuan mengasah tiga aspek yaitu afektif, kognitif, serta psikomotorik (Asniar et al., 2015). Pendidikan IPA berperan besar terhadap persiapan anak untuk menjalani kehidupan. IPA dapat dikatakan adalah proses serta produk, dengan teori, konsep, serta fakta yang ada di dalamnya (Wedayanti et al., 2015). 
Salah satu kunci untuk sukses dalam dunia pendidikan, perlu pemahaman yang baik tentang model pembelajaran yang dapat menjadi penunjang kelancaran pelaksanaan pendidikan, salah satu model pembelajarann adalah model pembelajaran terpadu. Semua tingkat pendidikan dapat menerapkan model ini, baik itu tingkat dasar, tingkat menengah pertama, dan tingkat menengah keatas (Nisak \& Susasntini, 2013). Model pembelajaran terpadu adalah pendekatan belajar bagi peserta didik untuk dapat aktif di dalamnya. Pada saat ini guru merasa bahwa pembelajaran lebih cenderung menerapkan metode ceramah, yang tidak menutup kemungkinan untuk siswa menjadi pasif dan kurang aktif dalam mencari materi secara mandiri (Timang et al., 2013). Pada kenyataanya, dengan menerapkan cara konvensional atau ceramah. Yang mengakibatkan siswa tidak dapat terlibat aktif serta kurang memperoleh hasil belajar yang diarapkan. Tentunya rasa bosan akan muncul untuk pembelajaran seperti itu yang dilakukan terus-menerus, sehingga dapat menjadikan siswa kurang dapat memahami materi dengan baik (Septiarini, 2015). Pembelajaran IPA diajarkan secara tradisional, serta diajarkan secara terpisah, belum secara terpadu (Yunus et al., 2016). Antara topik dan konsep satu sama lain saling memiliki keterhubungan pada model pembelajaran connected. Sehingga efisien dari pembelajaran dapat tercapai dengan diterapkanya pembelajaran terpadu tipe connected, juga dapat membuat guru melakukan inovasi pengembangan pembelajaran selanjutnya (Ariana et al., 2018).

Keterampilan dan pengetahuan akan model pembelajaran dapat menjadi kunci sukses dalam pelaksanaan kegiatan belajar mengajar. Ketertarikan siswa dapat diperoleh denan meerapkan pembelajaran dengan model yang bervariasi, model pembelajaran IPA terpadu memiliki peranan yang nyata dalam pembelajaran (Suriyani et al., 2017). Keefektifan penggunaan model connected pada pembelajaran IPA terpadu, antara lain diteliti oleh Nasution \& Ratnawulanf (2018), yang menuliskan bahwa ada peningkatan hasil belajar. Juga Nisak \& Susasntinif (2013) pada penelitianya mengungkapkan jikalau penerapan model connected dapat menggapai kesuksesan belajar. Karena pada tipe connected, pembelajaran berpusat pada siswa (Ningsih et al., 2017). Model connected saling terhubung yang dikaitkan dengan konsep dan keterampilan dalam satu bidang studi (Taqiya et al., 2019). Model connected terkait satu sama lain. Diharapkan siswa dapat menghubungkan dengan baik keterkaitan materi antara satu dengan yang lainya pada pelajaran IPA dengan diterapkanya pembelajaran terpadu connected, sehingga kesuksesan belajar dapat tercapai (Astiti, Engge, et al., 2020). Penelitian ini dilakukan dengan tujuan untuk mengetahui, mendeskripsikan, menganalisis serta mempelajari lebih dalam terkait pembelajaran IPA Terpadu model connected yang dikemukakan oleh Forgarty di Indonesia.

\section{METODE PENELITIAN \\ Latar Belakang Umum}

Berdasarkan studi literatur terkait pembelajaran IPA di Indonesia, menunjukkan bahwa kegiatan atau proses pembelajaran masih belum dilaksanakan secara terpadu, yaitu kegiatan mengajar antara mata pelajaran satu dengan mata pelajaran yang lainya masih terpisah dan tidak adanya keterkaitan satu dengan yang lain, sehingga dapat mengurangi peluang untuk dapat tercapainya tujuan belajar. Oleh karena itu, diharapkan dengan dilaksanakanya pembelajaran IPA terpadu dapat membantu keterlaksanaan kegiatan belajar mengajar dengan baik serta dapat tercapainya tujuan belajar. 


\section{Sampel / Peserta / Grup}

Penelitian ini adalah studi literatur yang merupakan subjek penelitian, dimana data penelitian didapatkan dari kajian literatur berupa karya tulis artikel ilmiah yang relevan tentang implementasi IPA terpadu tipe connected tahun 2012 - 2021.

\section{Instrumen dan Prosedur}

Penelitian ini dilakukan dengan menggunakan jenis model penelitian kualitatif dengan teknik analisis studi literatur, dimana data penelitian didapatkan dari kajian literatur berupa karya tulis artikel ilmiah yang relevan tentang implementasi IPA terpadu tipe connected tahun 2012 - 2021. Metode pengumpulan data secara studi literatur dilakukan dengan mengambil topik terkait yang relevan dengan penelitian, yang selanjutnya dikaji lebih dalam.

\section{Analisis data}

Penelitian ini untuk memperoleh data, penulis menganalisis dan mengadopsi hasil karya tulis ilmiah dari penelitian terdahulu.

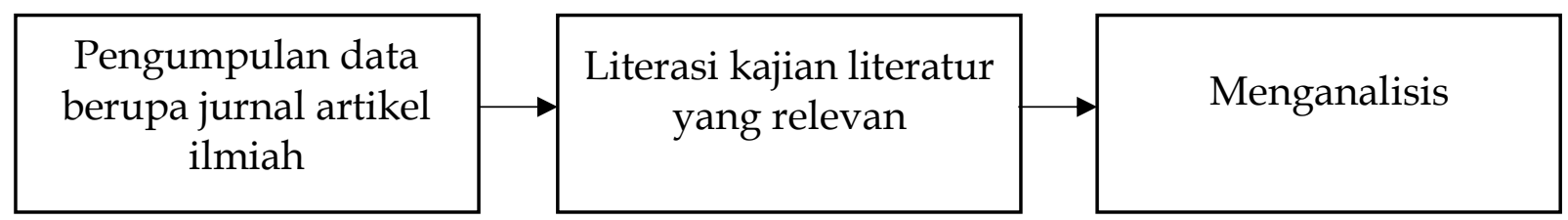

Gambar 1. Alur metode analisis data

\section{HASIL DAN DISKUSI}

Penelitian ini dilakukan dengan menggunakan metode penelitian kajian studi literatur untuk penelitian yang relevan pada tahun 2012 sampai tahun 2021. Rangkuman penelitian terdapat pada tabel di bawah ini :

Tabel 1. Kajian literatur 2012-2021

\begin{tabular}{|c|c|c|}
\hline $\begin{array}{l}\text { Penulis } \\
\text { (Tahun) }\end{array}$ & $\begin{array}{c}\text { Sampel } \\
\text { penelitian }\end{array}$ & Temuan \\
\hline $\begin{array}{l}\text { (Oktafita } \\
\text { sari et al., } \\
2021 \text { ) }\end{array}$ & Siswa SD & $\begin{array}{l}\text { * Penggunaan LKPD tipe connected, sehingga terlaksana } \\
\text { pembelajaran efektif dengan keterangan baik sekali }\end{array}$ \\
\hline $\begin{array}{l}\text { (Astiti, } \\
\text { Engge, et } \\
\text { al., 2020) }\end{array}$ & Siswa SMP & $\begin{array}{l}\text { * Prosedur pengembangan dilakukan menggunakan } \\
\text { langkah 4D, (1) analisis studi pustaka, (2) mendesain } \\
\text { bahan ajar, (3) pengembanan bahan ajar dengan } \\
\text { validasi oleh } 3 \text { ahli, (4) desimilasi tipe connected } \\
\text { * Pengambilan data menggunakan angket dengan } \\
\text { instrumen penilaian kelayakan bahan ajar oleh BSNP }\end{array}$ \\
\hline $\begin{array}{l}\text { (Astiti, } \\
\text { Yusuf, et } \\
\text { al., 2020) }\end{array}$ & Siswa SMP & $\begin{array}{l}\text { * Hasil penilaian ahli menunjukkan bahan ajar layak } \\
\text { untuk digunakan } \\
\text { * Berdasarkan respon tanggapan siswa, kegiatan } \\
\text { pembelajaran terpadu tipe connected ini perlu } \\
\text { diajarkan untuk kedepanya }\end{array}$ \\
\hline
\end{tabular}






(Alfikri et Siswa SMP al., 2019)

(Nasutio

Ratnawu

lan, 2018)

(Arif,

2018)

(Ariana

et al.,

2018)

(A.

Fitriani et

al., 2018)

Siswa SMP

Siswa SMP

Siswa SMA

Siswa SMP n \&

(Ningsih Siswa SMP

et al., 2017)
(Malasari Siswa SMA $\&$
Suyono, 2017)

Data didapat melalui pre tes dan post tes

Terdapat pengaruh pada hasil belajar siswa saat menggunakan IPA Terpadu tipe connected

Jenis penelitian semu (kuasi experimental reseach)

Hasil penelitian berupa kompetensi aspek pengetahuan dan aspek keterampilan

Terdapat perbedaan hasil belajar pada saat penggunaan buku terpadu tipe connected

Tujuan penelitian untuk meningkatkan prestasi belajar siswa

Kelas kontrol menunjukkan hasil yang berbeda dengan kelas eksperiment

Tujuan penelitian untuk mengetahui pengaruh terhadap prestasi belajar siswa

Data diambil dari pre tes serta post tes

Setelah penggunaan model connected ada peningkatan hasil belajar

Tujuan penelitian mengetahui perbedaan pelaksanaan pembelajaran IPA terpadu antara tipe connected denggan webbed

Metode penelitian secara kuasi eksperimen

Hasil penelitian menunjukkan hasil sangat baik pada tipe webbed sedangkan hasil baik pada tipe connected

Siswa SMP \# Tujuan penelitian mengetahui pengaruh penggunaan perangkat ajar IPA terpadu tipe connected

Rancangan penelitian adalah tes akhir dan awal

Data dianalisis secara kuantitatif dan deskriptif

Hasil penelitian ialah pengetahuan siswa meningkat, serta kategori sangat baik untuk indikator ketuntasan belajar siswa

Model penelitian kuantitatif tes akhir dan awal

Hasil penelitian keterlaksanaan percobaan berkategori sangat baik, serta pemahaman siswa meningkat setelah diterapkan pembelajaran IPA terpadu tipe connected 


\begin{tabular}{ll}
\hline (Suriyani & Siswa SMP \\
et al., & \\
$2017)$ &
\end{tabular}

(Mulyani Siswa MA et al., 2017)

\section{(Ridyah} \& Sriyati, 2019)

(Kurniaw ati et al., 2016)

(Yunus et al., 2016)

(Septiari Siswa SD ni, 2015)

(Wedaya nti et al., 2015)

Siswa SMP

Siswa SMP

Siswa SD
Tujuan penelitian untuk mengetahui pengaruh terhadap kemampuan berpikir kritis

Data didapatkan menggunakan tes

Data dianalisis secara deskriptif

Didapatkan hasil penelitian yaitu kelas eksperimen lebih tinggi dari kelas kontrol dalam hal kemampuan berpikir kritis

Tujuan penelitian mengetahui pengaruh terhadap pemahaman konsep serta penalaran saat diterapkanya pembelajaran connected

Penelitian kuasi eksperimen

Teknik pengumpulan data berupa tes

Terdapat perbedaan pemahaman antara pembelajaran konvensial dan connected yang diperoleh siswa Tujuan penelitian yaitu untuk mengidentifikasi peningkatan keterampilan proses sains siswa

Model penelitian tes awal akhir

* Hasil penelitian menunjukkan bahwa keterampilan proses sains didapat setelah siswa diajar dengan IPA terpadu connected

Kuasi eksperiment

Teknik pengambilan data yaitu purposive sampling

Data diambil dengan soal tes

Kesimpulan penelitian adalah ada efek yang signifikan dalam menggunakan lembar kerja siswa berdasarkan SAVI dengan menggunakan model connected

Siswa SMP \# Pre- eksperimen

Data didapat melalui soal tes pilihan ganda

Hasil analisis deskriptif didapatkan bahwa hasil belajar siswa meningkat pada saat diajar menggunakan pembelajaran IPA terpadu

Tujuan penelitian untuk mengetahui adanya Pengaruh Model Connected

Jenis penelitian kuantitatif

Hasilnya adalah kelas eksperimen nilainya lebih tinggi daripada kelas kontrol

Tujuan penelitian untuk mengetahui perbedaan hasil belajar IPA antara siswa yang belajar menggunakan model pembelajaran connected dengan siswa yang menggunakan pembelajaran konvensional

Data dianalisis secara deskriptif

Ada perbedaan hasil belajar siswa 
(Asniar Siswa SMP \& Tujuan penelitian : (1) menghasilkan software, (2)

et al.,

2015)

(Sumiant Siswa SD

ini et al.,

2014)

(Yanti et Siswa SD

al., 2014)

(Timang Siswa SMP

et al.,

2013)

(Maryant

o, 2013)

(Masduki Siswa SMP

\&

Rahayu,

2013)

(Oktama

gia et al.,

2013)

Siswa SMA menguji keefektifan terhadap hasil belajar

Instrumen penelitian berupa lembar tes literasi sains pilihan ganda

Hasil penelitian ada beda yang signifikan antara kelas kontrol dengan kelas eksperimen

Tujuan penelitian yaitu untuk mengetahui perbedaan hasil belajar siswa

Jenis penelitian semu

Data dikumpulkan dengan tes objektif

Hasil penelitian menunjukkan ada perbedaan hasil belajar

Tujuan penelitian untuk mengetahui perbedaan prestasi belajar

jenis penelitian eksperimen semu

* penggunaan model connected mempengaruhi prestasi belajar

Jenis kuasi eksperiment

Data dikumpulkan menggunakan menggunakan tes esai yang terdiri dari lima soal

Kelas eksperiimen dan kontrol memperoleh hasil yang berbeda Metode penelitian berupa eksperimen

Tenik pengumpulann data melalui rekam, test, serta foto

Data dianalisis secara deskriptif

Hasil penelitian terdapat perbedaan yang signifikan terhadap hasil belajar siswa

Siswa yang diajar menggunakan model connected memperoleh rerata nilai 84 , sementara siswa yang diajar dengan model konvensional mendapatkan rerata nilai 77,3

Perangkat pembelajaran divalidasi oleh dosen ahli

Hasil penelitian menyatakan jika perangkat pembelajaran menurut pendapat ahli sangat layak, dapat meningkatkan hasil belajar siswa, serta hasil angket menunjukkan sikap positif dari siswa terhadap perangkat pembelajaran

Siswa SMP \# Tujuan penelitian untuk menetahui hasil belajar siswa Instrumen penelitian berupa lembar penilaian hasil belajar

Hasil penelitian mennjukkan bahwa terdapat pengaruh tipe pembelajaran terintegrasi terhadap hasil belajar fisika IPA 
(S. Siswa SMP

Fitriani et

al., 2012)

(Sari et Siswa SD

al., 2012)

(Partini Siswa SD

et al.,

2012)

(Makhru Siswa SMP

S \&

Hadipra

yitno,

2012)

(Putra et Siswa SD

al., 2012)
Tujuan penelitian untuk mengetahi hasil belajar dari perbandingan penggunaan pedekatan SETS dan nonSETS

Penentuan sampling secara purposive sampling

Hasil penelitian menunjukkan presentase ketuntasan hasil belajar pada kelas eksperimen 90\%, sedangkan pada kelas kontrol $79 \%$

Tujuan penelitian untuk mengetahui hasil belajar siswa Jenis penelitian quasi eksperiment

Data diabil acak

Data berupa hasil tes belajar IPA

Hasi penelitian menyatakan model connected dan konvensional berbeda hasil belajar setelah diterapkan

- Penelitian untuk mengetahui ada beda penggunaan pembelajara connected dan konvensional

Data didapatkann dari tes

Hasil penelitian menunjukkan terdapat perbedaan hasil belajar antara penerapan model connected dengan konvensional

Tujuan penelitian untuk mengetahui keefektifan perangkat pembelajaran

Hasi penelitian dengan pendekatan IPA Terpadu tipe connected pada materi tekanan hidrostatis menunjukkan prosentase $94,74 \%$ dengan respon siswa sangat baik

Tujuan penelitian mengetahui perbandinggan hasil belajar siswa dengan pembelajaran terpadu terhadap konvensional

Desain penelitian berupa desain penelitian eksperimen semu

Pengambilan data menggunakan tes objektif

Model pembelajaran langsung kuragg berpengaruh terhadap hasil belajar dibandingkan dengan model terpadu connected

Berdasarkan tabel diatas tentang beberapa penelitian yang relevan mulai dari penelitian tahun 2012 sampai dengan penelitian tahun 2021 dapat ditarik kesimpulan bahwa pengunaan pembelajaran IPA terpadu model connected memiliki pengaruh yang baik terhadap pembelajaran, mulai dari pengaruh terhadap hasil belajar siswa, pengaruh terhadapat minat belajar siswa, serta pengaruh terhadap pemahaman yang dimiliki siswa. Sehingga pembelajaran IPA terpadu model connected dapat dijadikan referensi kedepanya.

\section{Karakteristik Model Connected}

Pembelajaran IPA terpadu model connected merupakan tipe pembelajaran yang dapat dijadikan referensi mengajar untuk guru dalam menyampaikan pembelajaran di kelas. Pembelaaran terpadu model connected adalah model penggabungan, dengan gambaran 
model yang menghungkan beberapa bidang ilmu satu dengan yang lainya (Alfikri et al., 2019). Model connected adalah menghubungkan materi pembelajaran satu sama lain tanpa disadari oleh siswa (Ridyah \& Sriyati, 2019). Model connected adalah pembelajaran yang mengaitkan ide-ide, konsep-konsep, dan materi-materi semester ini dengan semester berikutnya (Sumiantini et al., 2014).

\section{Trend Penelitian}

Model pembelajaran terpadu tipe connected berbantuan media berbasis gambar diterapkan pada siswa SD (Putra et al., 2012). Pendidikan seni budaya terpadu menerapkan moel connected sebagai pembelajaran yang disarankan (Maryanto, 2013). Membandingkan hasil belajar siswa yang belajar menggunakan model terpadu connected dengan konvensional jenjang SD (Yanti et al., 2014).

\section{Keunggulan Model Connected}

Kelebihan pembelajaran terpadu model connected adalah belajar dapat menjadi efektif dan efisien, karena dalam proses pembelajaranya saling terhubung baik itu konsep, materi, ataupun ide. Proses pembelajaran connected saat mengajar dilakukan dengan menghubungkan beberapa materi, konsep, atau keterampilan yang saling terkait (Kurniawati et al., 2016). Model pembelajaran connected adalah kerangka konseptual untuk mengajar secara terhubung dan terstruktur (Mulyani et al., 2017). Model connected mengaitkan pokok bahasan satu dengan lainya, keterampilan satu dengan lainya, baik pekerjaan hari ini dengan hari lainya (Malasari \& Suyono, 2017).

\section{Saran Penerapan Model Connected}

Belajar adalah untuk mencapai tujuan belajar, yang salah satunya dapat dicapai dengan menggunakan pembelajaran terpadu model connected. Model pembelajaran terpadu tipe connected berpengaruh terhadap hasil belajar dibandingkan dengan model pengajaran langsung (Putra et al., 2012). Hasil penelitian menunjukkan terdapat perbedaan hasil belajar antara penerapan model connected dengan konvensional (Partini et al., 2012). Hasi penelitian menyatakan jika ada perbedaan yang signifikan hasil belajar IPA yang diajar dengan model terpadu connected dengan pembelajaran konvensional (Sari et al., 2012).

\section{KESIMPULAN}

Penelitian terkait model connected pada pembelajaran IPA terpadu mulai tahun 20122021 memiliki tujuan untuk meningkatkan hasil belajar, meningkatkan kemampuan pemecahan masalah, serta meningkatkan minat belajar siswa. Penelitian ini merupakan penelitian dengan metode kajian literatur yang memiliki batasan pembahasan terkait penelitian yang relevan mengenai pembelajaran IPA terpadu model connected. Melihat hasil penelitian sebelumnya, maka pembelajaran IPA terpadu model connected merupakan tipe pembelajaran yang dapat dijadikan sebuah referensi mengajar untuk guru meyampaikan pembelajaran di depan kelas. Pembelajaran IPA terpadu model connected diharapkan mampu memberikan dampak yang positif pada kegiatan dan hasil belajar siswa. Berdasarkan kajian literatur yang relevan dengan penelitian ini mulai dari penelitian tahun 2012 - 2021, sehingga penelitian ini dapat dijadikan sebagai referensi untuk melakukan penelitian kedepanya terkait pelaksanaan IPA terpadu model connected, serta diperoleh hasil mendasar kesimpulan dari penelitian yang relevan 
tersebut menunjukkan bahwa dengan diterapkanya pembelajaran IPA terpadu model connected berdampak positif terhadap hasil belajar, kemampuan pemecahan masalah, dan minat belajar siswa.

\section{UCAPAN TERIMA KASIH}

Penulis bersyukur kepada Allah yang senantiasa memberi rahmat serta hidayahnya dan senantiasa selalu diberikan kesehatan ditengah pandemi Covid-19. Tidak terlupa ucapan terima kasih untuk semuanya yang membantu tersusunya artikel ilmiah ini, semoga dengan ditulisnya artikel ini dapat memberikan manfaat bagi penulis dan juga pembaca. Amin.

\section{DAFTAR PUSTAKA}

Alfikri, A., Ratnawulan, \& Gusnedi. (2019). Pengaruh Buku Teks IPA Terpadu Tipe Connected Tema Indera Pendengaran Dan Sistem Sonar Pada Makhluk Hidup Terhadap Hasil Belajar Siswa Kelas VIII SMPN 7 Padang. Pillar of Physics Education, 12(4), 737-744. http:/ / dx.doi.org/10.24036/7350171074

Ariana, I., Caronge, M. W., \& Lahming, L. (2018). Peningkatan Prestasi Belajar pada Mata Pelajaran Alat dan Mesin Pertanian Melalui Model Pembelajaran Terpadu Tipe Connected pada Siswa Kelas XII ATPH SMK Negeri 2 Bulukumba. Jurnal Pendidikan Teknologi Pertanian, 1(1), 1-12. https:/ / doi.org/10.26858/jptp.v1i1.6214

Arif, R. M. (2018). Pengembangan Bahan Ajar IPA Terpadu Model Connected untuk Meningkatkan Prestasi Belajar Siswa SMP. Jurnal Pendidikan Hayati, 4(1), 1-9. https:/ / doi.org/10.33654/jph.v4i1.444

Asniar, Permanasari, A., \& Mudzakir, A. (2015). Efektivitas Software Pembelajaran IPA Terpadu Model Connected untuk Meningkatkan Literasi Sains Siswa pada Aspek Konten dan Konteks Tema Rokok dan Kesehatan. Prosiding Seminar Nasional Pendidikan Sains, 515-523.

Astiti, K. A., Engge, B. Y., \& Bani, M. D. S. (2020). Pengembangan Bahan Ajar IPA Terpadu Tipe Connected Pada Materi Energi. Jurnal Pendidikan Dan Pembeajaran Sains Indonesia, 3(2), 102-111. https:/ / doi.org/10.23887/jppsi.v3i2.29002

Astiti, K. A., Yusuf, Y. M. H., \& Kalendiwau, A. J. W. (2020). Pengembangan Bahan Ajar IPA Terpadu Tipe Connected pada Materi Zat dan Karakteristiknya. Jurnal Ikatan Alumni Fisika Universitas Negeri Medan, 6(4), 22-28.

Fitriani, A., Mulyaningrum, E. R., \& Rachmawati, R. C. (2018). Komparasi Pembelajaran IPA Terpadu Tipe Connected dan Webbed melalui LSLC terhadap Hasil Belajar Kognitif Siswa di SMP Negeri 11 Semarang. Florea: Jurnal Biologi Dan Pembelajarannya, 5(2), 91. https:/ / doi.org/10.25273/florea.v5i2.3147

Fitriani, S., Binadja, A., \& S, K. I. (2012). Penerapan Model Connected Bervisi Science Environment Technology pada Pembelajaran IPA Terpadu. Unnes Science Education Journal, 1(2), 111-118.

Kurniawati, A., Djamas, D., \& Ratnawulan. (2016). Pengaruh Penerapan LKPD Berbasis Pendekatan SAVI (Somatic Auditory Visual Intelegency) dalam Pembelajaran IPA Terpadu Tipe Connectted terhadap Pencapaian Kompetensi IPA Peserta Didik Kelas VIII SMPN 12 Padang. Pillar of Physics Education, 8, 1-8. https:/ / doi.org/10.24036/2455171074

Makhrus, M., \& Hadiprayitno, G. (2012). Penerapan Perangkat Pembelajaran Fisika Berorientasi Pembelajaran IPA Terpadu Tipe Connected. Jurnal Pendidikan Dan 
Pembelajaran, 19(2), 237-242.

Malasari, P. N., \& Suyono. (2017). Penerapan Model Pembelajaran Inkuiri Terbimbing yang Dipadukan Model Nested dan Connected untuk Membangun dan Memperkuat Konsepsi Laju Reaksi. UNESA Journal of Chemical Education, 6(2), 262268. https:/ / doi.org/10.26740/ujced.v6n2.p

Maryanto. (2013). Pengaruh Pendekatan Terpadu model Connected Dalam Pembelajaran Seni Musik Terhadap Pemahaman Berbagai Kompetensi Siswa di SMAN 13 Banjarmasin. Jurnal Paradigma, 8(1), 87-102.

Masduki, H., \& Rahayu, Y. S. (2013). Pengembangan Perangkat Pembelajaran IPA

Terpadu Model Connected dengan Menggunakan Pendekatan Guided Inquiry untuk SMP pada Topik Alkohol dan Rokok. Jurnal Pendidikan Sains E-Pensa, 1(1), 246-252.

Mulyani, A., Hartanto, \& Zamzaili. (2017). Pengaruh Model Pembelajaran Connected Mathematics Project terhadap Kemampuan Pemahaman Konsep dan Penalaran Matematis di Madrasah Aliyah. Jurnal Pendidikan Matematika Raflesia, 2(1), 118-127. https:/ / doi.org/10.31186/jpmr.v2i1.4086

Nasution, A. R. S., \& Ratnawulan. (2018). Pengaruh Buku Siswa IPA Terpadu Tipe Connected Bermuatan Karakter dengan Tema Fluida Darah terhadap Hasil Belajar Siswa Kelas VIII SMPN 8 Padang. Pillar of Physics Education, 11(3), 57-64. https:/ / doi.org/10.24036/7350171074

Ningsih, R., Susantini, E., \& Sugiarto, B. (2017). Pengaruh Penggunaan Perangkat Pembelajaran IPA Terpadu Tipe Connected terhadap Kompetensi Pengetahuan dan Keterampilan Siswa SMP Negeri 2 Kelumpang Tengah. JPPS (Jurnal Penelitian Pendidikan Sains), 6(2), 1355. https:/ / doi.org/10.26740/jpps.v6n2.p1355-1362

Nisak, K., \& Susasntini, E. (2013). Pengembangan Perangkat Pembelajaran IPA Terpadu Tipe Connected pada Materi Pokok Sistem Ekskresi untuk Kelas IX SMP. Jurnal Pendidikan Sains E-Pensa, 1(1), 81-84.

Oktafitasari, L. W., Roesminingsih, M. V., \& Suhanadji. (2021). Pengembangan Lembar Kerja Peserta Didik (LKPD) Model Terpadu Tipe Connected Berbasis Pendekatan Saintifik untuk Meningkatkan Hasil Belajar Siswa. Jurnal Pendidikan Dan Pembelajaran Kimia, 9(1), 88-103. https:/ / doi.org/10.23960/jpk.v9.i1.202008

Oktamagia, D. W., Fauzi, A., \& Hidayati. (2013). Pengaruh Pembelajaran Terpadu Tipe Connected terhadap Hasil Belajar IPA Fisika pada Materi Cahaya dan Alat Optik di Kelas VIII SMPN 1 Sungai Tarab. Pillar of Physics Education, 2, 25-32. https://doi.org/10.24036/731171074

Partini, N. K., Partadjaja, T. R., \& Suartama, I. K. (2012). Pengaruh Model Pembelajaran Terpadu Connected terhadap Hasil Belajar PKN Siswa Kelas IV SDN 28 Dangin Puri. https://doi.org/10.23887/jjpgsd.v1i1.775

Putra, I. G. A. M., Murda, I. N., \& Agustiana, I. G. A. T. (2012). Pengaruh Model Pembelajaran Terpadu Tipe Connected Berbantuan Media Gambar terhadap Hasil Belajar IPA Siswa Kelas IV SD. https:/ / doi.org/10.23887/jjpgsd.v1i1.918

Ridyah, S. W., \& Sriyati, S. (2019). Pembelajaran IPA Terpadu dengan Tipe Connected dengan Model Experiential Learning untuk Meningkatkan Keterampilan Proses Sains Siswa SMP. EDUSAINS, 8(2), 122-127. https:/ / doi.org/10.15408/es.v8i2.1802 Sari, N. W. Y., Suniasih, N. W., \& Sujana, I. W. (2012). Pengaruh Model Pembelajaran Terpadu Tipe Connected terhadap Hasil Belajar IPA Siswa Kelas IV.

Septiarini, M. (2015). Pengaruh Model Connected Didukung Media Fotografi dalam 
Kegiatan Mengaplikasikan Teknologi Sederhana. In T. P. P. S. D. A. pada Siswa Kelas IV SD Pawyaan Daha. Universitas Nusantara PGRI Kediri.

Siti Nur Rahma, \& Hikmasanti Agustin. (2021). Profil Implementasi Model Integrated pada Pembelajaran IPA di Indonesia (2012-2021). Jurnal Inovasi Penelitian Dan Pengabdian Masyarakat, 1(1), 1-15. https://doi.org/10.53621/jippmas.v1i1.1

Sumiantini, N. K., Parmiti, D. P., \& Pudjawan, K. (2014). Pengaruh Model Pembelajaran Terpadu Tipe Connected Berbantuan Media Komik terhadap Hasil Belajar IPA Kelas V. E-Journal MIMBAR PGSD Universitas Pendidikan Ganesha Jurusasn PGSD, 2(1). https:/ / doi.org/10.23887/jjpgsd.v2i1.3790

Suriyani, H. I., Sabilu, M., \& Safilu. (2017). Pengaruh Pembelajaran Terpadu Tipe Connected Menggunakan Pendekatan Scientific terhadap Keterampilan Berpikir Kritis Siswa pada Materi Sistem Pencernaan Manusia di kelas VIII SMP Negeri 10 Kendari. J. AMPIBI, 2(1), 75-83. https:/ / doi.org/10.36709/ampibi.v2i1.5060

Taqiya, T. B., Nuroso, H., \& Reffiane, F. (2019). Pengaruh Model Pembelajaran Terpadu Tipe Connected Berbantu Media Video Animasi. Mimbar PGSD Undiksha, 7(3), 289295. https:/ / doi.org/10.23887/jjpgsd.v7i3.19492

Timang, R., Tangkas, I. M., \& Sakung, J. (2013). Studi Komparatif Hasil Belajar Siswa melalui Pembelajaran Terpadu Model Connected Berbasis Kooperatif pada Bidang Studi IPA dengan Materi Bahan Kimia dalam Makanan pada Siswa Kelas VIII SMP Negeri 19 Palu. J. Akademika Kim, 2(2), 68-75.

Wedayanti, D. P. S., Suarjana, I. M., \& Widiana, I. W. (2015). Pengaruh Model Pembelajaran Terpadu Tipe Connected terhadap Hasil Belajar IPA Siswa Kelas IV Sekolah Dasar. E-Journal PGSD Universitas Pendidikan Ganesha Jurusan PGSD, 33(1). https://doi.org/10.23887/jjpgsd.v3i1.5722

Yanti, L. E., Sedanayasa, G., \& Syahruddin. (2014). Pengaruh Model Connected terhadap Prestasi Belajar Matematika Siswa Kelas V SD Gugus I Karangasem. E-Journal MIMBAR PGSD Universitas Pendidikan Ganesha Jurusasn PGSD, 2(1). https: / / doi.org/10.23887/jjpgsd.v2i1.3814

Yunus, S. R., Hadir, H. K., \& Mamin, R. (2016). Peningkatan Hasil Belajar Peserta Didik melalui Pembelajaran IPA Terpadu Model Connected. Jurnal Sainsmat, 5(2), 183190. https:/ / doi.org/10.35580/sainsmat5264472016

\footnotetext{
* M. Raynaldi Rosyidi Zamil (Corresponding Author)

Universitas Negeri Surabaya,

Jl. Ketintang, Ketintang, Kec. Gayungan, Kota Surabaya, Jawa Timur, 60231, Indonesia

Email: raynaldi.18034@mhs.unesa.ac.id

Putrie Syifa Udyaningsih

Universitas Negeri Semarang,

Kampus Sekaran, Kecamatan Gunungpati, Kota Semarang, Jawa Tengah, 50229, Indonesia

Email: putriesyifa@students.unnes.ac.id
} 